Brazilian Journal

of Chemical

Engineering

\title{
BIODEGRADATION OF ACACIA AND CHESTNUT TANNINS BY NATIVE ISOLATES OF THE GENUS Penicillium AND Aspergillus
}

\author{
Franciela Spier $^{1 *}$ and Mariliz Gutterres ${ }^{1}$ \\ ${ }^{1}$ Universidade Federal do Rio Grande do Sul, Departamento de Engenharia Química, Laboratório de Couro e Estudos Ambientais, \\ Porto Alegre, RS, Brasil. E-mail: francielaspier@gmail.com - ORCID: 0000-0001-7818-1866; ORCID: 0000-0001-8939-2888
}

(Submitted: July 20, 2018 ; Revised: November 14, 2018 ; Accepted: December 10, 2018)

\begin{abstract}
In the present work, the potential of native isolates of fungi strains to biodegrade vegetable tannins used in the tanning industry was evaluated. Penicillium citrinum showed to be more efficient for consumption of acacia tannin, reaching $94.85 \%$. Aspergillus chevalieri needs a greater adaptation phase $(48 \mathrm{~h})$ in both acacia and chestnut medium, evidenced by the slow growth $\left(0.022 \mathrm{~h}^{-1}\right)$ and low biomass productivity $\left(0.31 \mathrm{~g} \cdot \mathrm{L}^{-1}\right.$. $\left.\mathrm{h}^{-1}\right)$. The acacia tannin presented a higher COD/BOD ratio (2.97) and lower total phenol content (68\%) when compared to chestnut tannin. In addition, there was greater consumption of this tannin in the cultivations, which contradicts previous reports and corroborates the results obtained with FTIR analysis that suggests the biodegradation of acacia by Penicillium citrinum and aethiopicum. The expressive results obtained demonstrated that the biodegradation of condensed tannins may be a promising alternative, with the potential to minimize tannery waste.

Keywords: Microbial degradation; Condensed tannin; Tannery waste.
\end{abstract}

\section{INTRODUCTION}

Vegetable tannins can be easily extracted with water from almost all plants (Tondi and Petutschnigg, 2015; Sundar and Muralidharan, 2017). They occur in bark, wood, fruits, fruit pods, leaves, roots, and plant galls and can accumulate in large quantities in certain organs or tissues of plants, being found mainly in the vacuoles of plants (Ricci et al., 2015). Vegetable tannins have the molecular weight between 500 and 3,000 Da and differ from most other phenolic compounds by their ability to form water-insoluble complexes with proteins, polysaccharides and alkaloids (Grasel and Ferrão, 2016). Considering their property to precipitate proteins, vegetable tannins have been traditionally explored to transform animal hides into leather (Haroun et al., 2013). This specific reactivity with proteins is called astringency, being the basis for their its use in the tanning industry (Khanbabaee and Ree, 2001).

Raw hides are susceptible to attack by microorganisms. The collagen must be stabilized by the tanning process in which tanning agents react with the collagen matrix, stabilizing it and avoiding its degradation (Fuck et al., 2011). Due to the stringent requirements imposed on tanning industry, the development and implementation of cleaner technologies for environmental protection becomes increasingly imperative (Plavan et al., 2009; Pillai and Archana, 2012). For tanning this involves effort for the substitution of chromium by other tanning substances, making use of a combination of materials of inorganic origin (aluminum, silica, zinc, etc.) and organic (vegetable tannins, synthetic tannins, resins, aldehydes, etc.) to provide the required leather characteristics like stiffness, UV resistance. (Covington and Lampard, 2004; Saravanabhavan et al., 2007; Maier et al., 2017).

After the tanning process, liquid effluent is generated containing high organic loads, phenolic compounds, proteins, fat and neutral salts. It is estimated that $15 \%$ of the tannin used in tanning is discarded in the effluent. Vegetable tanning effluents show high chemical oxygen demand (COD) and bio-

\footnotetext{
*Corresponding author: Franciela Spier - E-mail: francielaspier@gmail.com
} 
chemical oxygen demand (BOD) (Guanamani et al., 2001; Song and Burns, 2005). Due to the presence of tannins, the wastewaters are usually highly colored, which is very difficult to eliminate by common methods (He et al., 2007). They also exhibit long-term negative environmental effects, due to their toxicity for microorganisms (He et al., 2007; Teng et al., 2016). The toxicity of tannins can be associated with several mechanisms such as substrate deprivation, loss of metal ions, and inactivation of microbial adhesins, enzymes, and cell envelope transport proteins (Bhoite and Murthy, 2015).

Tannins are a heterogeneous group of polyphenols widely present in the plant kingdom (pteridophytes, gymnosperms and angiosperms), secondary metabolites for protective purposes (Falcão and Araújo, 2014). The chemical classification of tannins divides them into the groups of hydrolysable and condensed (Adamczyk et al., 2011). The hydrolyzable tannins are readily hydrolyzed by acids, alkalis or enzymes into a sugar or a related polyhydric alcohol (polyol) and a phenolic carboxylic acid (Haroun et al., 2013). The condensed tannins, also called proanthocyanidins, are oligomers and polymers composed of flavonoid units (Ricci et al., 2015). These compounds are used for many different applications, such as flocculants, anti-corrosion, tanning, adhesives, cement super plasticizers, pharmaceutical agents and foams (Grasel et al., 2016; Maier et al., 2017). A variety of vegetable tannins from different plants with different chemical constitutions and properties are used for tanning.

Tannin antimicrobial activity can be explained by their ability to complex irreversibly with proteins and therefore inhibit any activity (Maier et al., 2017). When vegetable tannins are present in sludge, anaerobic digestion does not establish due to the their high toxicity and concentration (Agustini et al., 2018). Tannins are very recalcitrant; the presence of aromatic rings constitutes the main obstacle for the treatment of effluents that present phenolic compounds in their composition. However, some microorganisms are resistant to tannins and have the ability to degrade them by the action of enzymes (Silva et al., 2010). The main sources of enzymes are microorganisms such as bacteria, yeast and filamentous fungi. However, the interesting aspect to use fungi in the treatment of effluents containing compounds of this nature is the great ability of these microorganisms to produce enzymes (tannases, cellulases, ligninases, peroxidases) which make them more accessible to biodegradation (Luke and Burton 2001). Among the filamentous fungi, Aspergillus and Penicillium are important tannase producers (Valera et al., 2015).

The elimination of wide ranges of pollutants and wastes from the environment is a prerequisite for promoting sustainable development of our society with low environmental impact. Environmental sustainability in leather processing is possible with the use of biotechnology and clean technologies in tanneries through organic tannins and adequate environmental management of the solid wastes and liquid effluents generated. In this context, the biodegradation of condensed and hydrolysable tannins by native Penicillium citrinum, Penicillium aethiopicum, Aspergillus chevalieri and Aspergillus oryzae was investigated in this paper.

\section{METHODOLOGY}

\section{Microorganisms}

Fungal strains were collected from stored corn (Penicillium citrinum, Penicillium aethiopicum, Aspergillus chevalieri) and rice flour (Aspergillus oryzae) sampled in Porto Alegre, RS, Brazil. The fungi were isolated from inoculation of a tissue plug obtained from mycelia identified as described by Ortiz-Monsalve et al. (2017) and gently provided by the Laboratory of Mycology of the Federal University of Rio Grande do Sul. The strains were maintained on potato dextrose agar slants at $4{ }^{\circ} \mathrm{C}$ until use. Subcultures were made every three months on potato dextrose agar slants with a inoculation loop and incubated at $25^{\circ} \mathrm{C}$ for 4 a 5 days. After this time, the tubes were kept under refrigeration. The fungi are registered in GenBank with the following access numbers: Penicillium citrinum (MH532414), Penicillium aethiopicum (MH675468), Aspergillus chevalieri (MH532415) and Aspergillus oryzae (MH569333).

\section{Shaken Flasks Cultivation}

Five agar plugs ( $7 \mathrm{~mm}$ of diameter), taken from the edge of an actively growing colony (Anastasi et al., 2011), were used to aseptically inoculate each $250 \mathrm{ml}$ shake flask containing $50 \mathrm{ml}$ of culture medium $(\mathrm{g} / \mathrm{l})$ : tannin (40.0), $\mathrm{KH}_{2} \mathrm{PO}_{4}(4.38),\left(\mathrm{NH}_{4}\right)_{2} \mathrm{SO}_{4}(8.76), \mathrm{CaCl}_{2}$ - $2 \mathrm{H}_{2} \mathrm{O}(0.088), \mathrm{MgSO}_{4} \cdot 7 \mathrm{H}_{2} \mathrm{O}(0.88), \mathrm{Na}_{2} \mathrm{MnO}_{4}$. $2 \mathrm{H}_{2} \mathrm{O}^{2}(0.0088), \mathrm{MnCl}_{2} \cdot 4 \mathrm{H}_{2} \mathrm{O}(0.018), \mathrm{FeSO}_{4} \cdot 7 \mathrm{H}_{2}^{4} \mathrm{O}$ (0.012) (Chávez-González et al., 2014). The flasks were incubated in an orbital shaker $(200 \mathrm{rpm})$ at $25^{\circ} \mathrm{C}$ for $120 \mathrm{~h}$. Vegetable tannins powder from black acacia and chestnut provided by Tanac S.A and Silvateam S.A respectively, were used as the main source of carbon. The assays were performed in triplicate.
Analytical methods
The determination of the tannin concentration in the medium was carried out on a spectrophotometer (T80 + UV / Vis Spectrometer (PG Instruments Ltd.) using a wavelength of $278 \mathrm{~nm}$ obtained by scanning. The absorbance values were converted to concentration $(\mathrm{g} / \mathrm{L})$ through a calibration curve previously plotted for each tannin. 
The biomass dry weight was determined after vacuum filtration through reweighed glass microfiber filters (Whatman, $45 \mu \mathrm{m}$ pore and $50 \mathrm{~mm}$ diameter) and drying at $105{ }^{\circ} \mathrm{C}$ to a constant weight (Baccar et al., 2011).

The determinations of total organic carbon (TOC) and total nitrogen $(\mathrm{TN})$ of the culture medium were performed in a total organic carbon analyzer (TOC-L Shimadzu) equipped with a total nitrogen measuring unit (TNM-L Shimadzu) and 8-port sampler (OCT-L Shimadzu). Total phenols were estimated as tannic acid equivalents, according to the Folin-Ciocalteau assay (Sartori et al., 2014). The physicochemical analyses of chemical oxygen demand (COD) and bio-chemical oxygen demand (BOD) were performed according to the procedure described by Eaton et al. (2005). These determinations were performed at the beginning of cultivations.

Biodegradation was assessed using Fourier transform infrared spectroscopy (FTIR). FTIR analysis was carried out (MIR-FTIR, Perkin Elmer, Frontier ${ }^{\mathrm{TM}}$ spectrometer) in the mid-IR region of $500-4000 \mathrm{~cm}^{-1}$ with 16 scan speed.

The experiments were performed in triplicate. The data were analyzed by analysis of variance and the Tukey test to verify the significant differences between the microorganisms under study, at a $95 \%$ confidence level ( $\mathrm{p} \leq 0.05$ ), using Statistica 5.0 software (Stat Soft Inc., USA).

\section{Calculation of growth parameters}

Maximum specific growth rate $\left(\mu_{\max }\right)$ was calculated at the exponential phase of growth using the following equation:

$\mu_{\max }=\frac{\left(\ln \mathrm{X}_{2}-\ln \mathrm{X}_{1}\right)}{\left(\mathrm{t}_{2}-\mathrm{t}_{1}\right)}$

in wich $X_{2}$ and $X_{1}$ are the mean of cell dry weights at the times $\mathrm{t}_{2}$ and $\mathrm{t}_{1}$, respectively.

Maximum biomass productivity $\left(\mathrm{P}_{\mathrm{X}_{\max }}\right)$ was calculated by:

$$
\mathrm{P}_{\mathrm{X}_{\max }}=\frac{\left(\mathrm{X}_{2}-\mathrm{X}_{1}\right)}{\left(\mathrm{t}_{2}-\mathrm{t}_{1}\right)}
$$

in wich $\mathrm{X}_{2}$ and $\mathrm{X}_{1}$ are the mean of biomass dry weights at the times $t_{2}$ and $t_{1}$, respectively.

Biomass yield on substrate $\left(\mathrm{Y}_{\mathrm{x} / \mathrm{s}}\right)$ was calculated by:

$\mathrm{Y}_{\mathrm{x} / \mathrm{s}}=\frac{\Delta \mathrm{X}}{\Delta \mathrm{S}}$

in which $\Delta \mathrm{X}$ and $\Delta \mathrm{S}$ are the amount of biomass production and the total amount of substrate consumed, respectively.

\section{RESULTS AND DISCUSSION}

\section{Shake flask cultivation}

Tannin concentration, biomass and $\mathrm{pH}$ in fungi cultivations containing acacia and chestnut tannin are shown in Figure 1. A previous evaluation of the influence of $\mathrm{pH}$ on tannin consumption and biomass production was carried out using $\mathrm{pH}$ of 3.5, 4.5 and 5.5 (data not shown). As no significant differences were found, it was decided to use the $\mathrm{pH}$ of the medium, without adjustment, around 4.5.

It was observed that the $\mathrm{pH}$ of the culture medium decreased during the first $72 \mathrm{~h}$ (Figure 1a and 1d) and from this point onwards, remained practically constant except for the cultivation of Aspergillus chevalieri where a constant decline of the $\mathrm{pH}$ was coupled with the increase in biomass production until the end of the cultivation. This can be explained by the fact that Aspergillus chevalieri requires a greater adaptation phase to the culture medium while the other microorganisms since the beginning of the cultivation presented intense microbial activity, resulting in a faster decrease of $\mathrm{pH}$. The $\mathrm{pH}$ changes of the medium throughout the culture are due to the metabolic activity of these microorganisms that have the capacity to produce organic acids. In this way the medium assumes acid values which represents a competitive advantage over other microorganisms (Kyriacou et al., 2005).

The growth curves (Figure 1b e 1e) demonstrated that the maximum biomass values were reached at 72 $\mathrm{h}$ for both acacia and chestnut cultivations, except for Aspergillus chevalieri, as also occurred for $\mathrm{pH}$. By observing the biomass concentration obtained for the different fungi, it appears that, in the cultures with acacia tannin, there was greater growth of fungi of the genus Penicillium. There were no significant differences between the species (citrinum and aethiopicum). The best results were obtained with these fungi using acacia tannin as substrate. In chestnut cultivations, however, the highest concentrations of biomass were reached by fungi of the genus Aspergillus. There was also no significant difference between Aspergillus species. It was observed, however, that Aspergillus chevalieri needs a greater adaptation phase $(48 \mathrm{~h})$ for both acacia and chestnut medium. In acacia medium this is evidenced by the slow growth $\left(0.022 \mathrm{~h}^{-1}\right)$ and low biomass productivity $\left(0.31 \mathrm{~g} . \mathrm{L}^{-1} \cdot \mathrm{h}^{-1}\right)$, as shown in Table 1. According to Kyriacou et al. (2005) the microbial activity is directly influenced by the amount of biomass, observing better removal of COD.

Lipid accumulation in oleaginous fungi has been demonstrated to occur when a nutrient in the medium becomes limited and the carbon source is present in excess (high $\mathrm{C} / \mathrm{N}$ ratio) (Khot et al., 2012). Nitrogen limitation is the most efficient condition for inducing lipogenesis. The results (Table 1) indicate that the $\mathrm{C} / \mathrm{N}$ 
A.

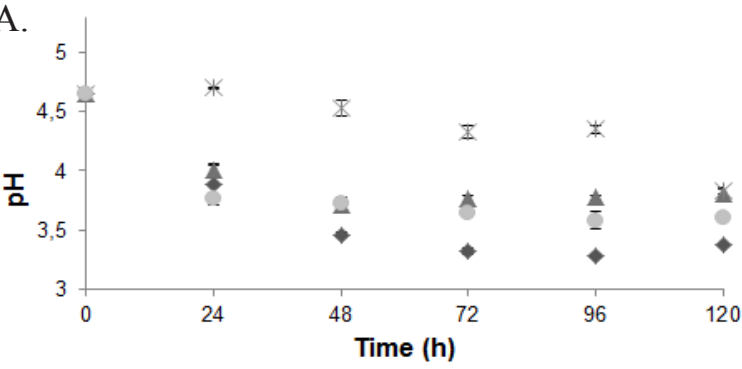

- Pe citrinum $\Delta$ Pe aethiopicum $*$ Asp chevalieri Asp oryzae

B.

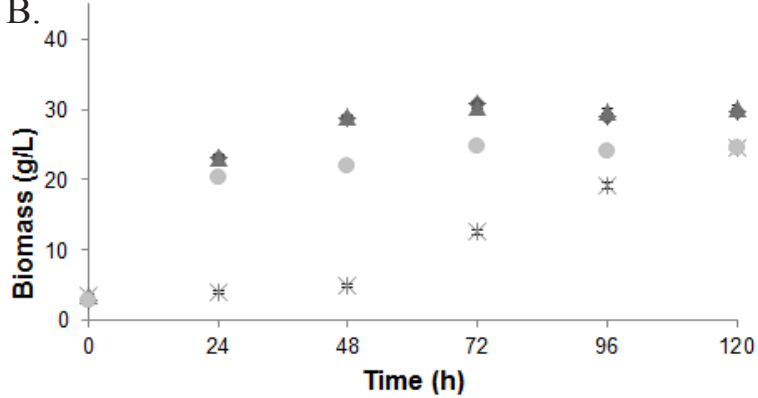

- Pe citrinum $\Delta$ Pe aethiopicum *Asp chevalieri Asporyzae

C.

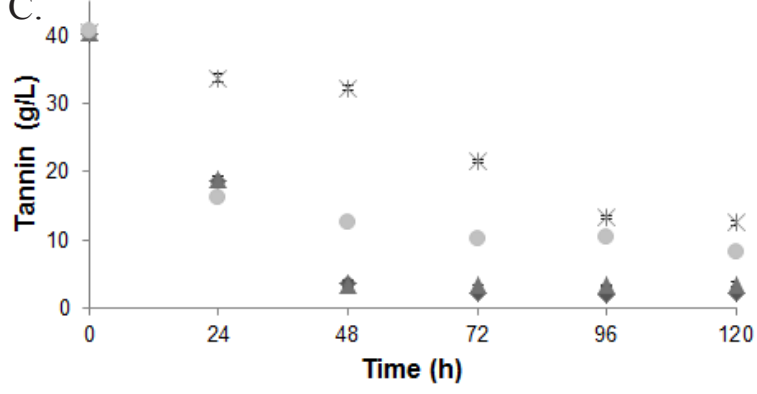

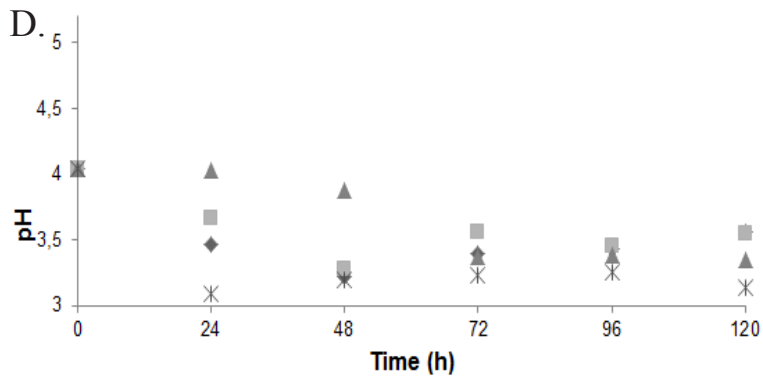

- Pe citrinum $\quad$ Pe aethiopicum $\Delta$ Asp chevalieri $*$ Asp oryzae

E.

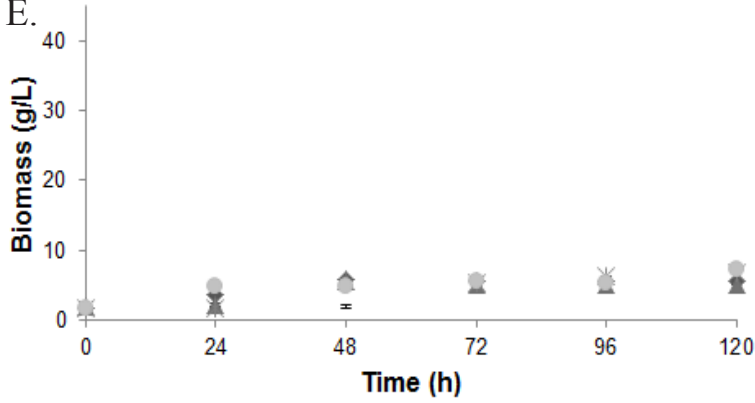

- Pe citrinum $\Delta$ Pe aethiopicum $*$ Asp chevalieri Asporyzae

F.

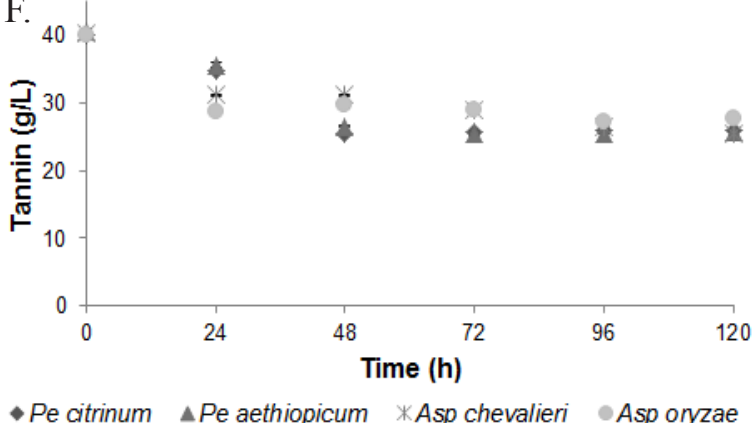

Figure 1. (a) $\mathrm{pH}$, (b) Biomass and (c) Tannin concentration in medium containing acacia tannin and (d) pH, (e) biomass and (f) tannin concentration in medium containing chestnut tannin along the cultivation time of Penicillium citrinum (•), Penicillium aethiopicum ( $\mathbf{\Delta})$, Aspergillus chevalieri $(*)$ and Aspergillus oryzae $(\bullet)$.

Table 1. Cultivation parameters, total phenols, total carbon and nitrogen, COD and BOD of the cultivations containing acacia and chestnut tannin as substrate.

\begin{tabular}{|c|c|c|c|c|c|}
\hline Fungi & $\begin{array}{l}\mathrm{X} \text { max } \\
\left(\mathrm{g} . \mathrm{L}^{-1}\right)\end{array}$ & $\begin{array}{c}\text { Tannin } \\
\text { consuption }(\%) \\
\end{array}$ & $\begin{array}{c}\mu_{\max } \\
\left(\mathbf{h}^{-1}\right)^{\mathbf{A}}\end{array}$ & $\begin{array}{c}P_{X \max } \\
\left(\text { g.L } \mathbf{L}^{-1} \cdot h^{-1}\right)^{B}\end{array}$ & $\begin{array}{c}Y_{x / s} \\
\left(\text { g.g } g^{-1}\right)^{B}\end{array}$ \\
\hline \multicolumn{6}{|c|}{ Acacia tannin } \\
\hline Penicillium citrinum & $30.86 \pm 0.11^{\mathrm{a}}$ & $94.85 \pm 0.45^{\mathrm{a}}$ & $0.033^{\mathrm{a}}$ & $0.84^{\mathrm{a}}$ & $0.74^{b}$ \\
\hline Penicillium aethiopicum & $30.39 \pm 0.38^{\mathrm{a}}$ & $91.45 \pm 0.75^{b}$ & $0.029^{\mathrm{b}}$ & $0.81^{\mathrm{a}}$ & $0.73^{b}$ \\
\hline Aspergillus chevalieri & $24.42 \pm 0.21^{\mathrm{b}}$ & $68.90 \pm 0.68^{c}$ & $0.022^{\mathrm{c}}$ & $0.31^{\mathrm{c}}$ & $0.76^{\mathrm{a}}$ \\
\hline Aspergillus oryzae & $24.77 \pm 0.04^{b}$ & $79.78 \pm 0.04^{\mathrm{d}}$ & $0.029^{b}$ & $0.72^{\mathrm{b}}$ & $0.68^{\mathrm{c}}$ \\
\hline \multirow[t]{2}{*}{ Medium* } & $\begin{array}{c}\text { Total phenols } \\
(\%)\end{array}$ & $\mathrm{C} / \mathrm{N}$ ratio & $\begin{array}{c}\mathrm{COD} \\
\left(\mathrm{mgO} 2 . \mathrm{L}^{-1}\right)^{\mathrm{B}}\end{array}$ & $\begin{array}{c}\text { BOD } \\
\left(\mathrm{mgO} 2 \cdot \mathrm{L}^{-1}\right)^{\mathrm{B}}\end{array}$ & $\mathrm{COD} / \mathrm{BOD}^{\mathrm{B}}$ \\
\hline & $68 \pm 0.9^{\mathrm{b}}$ & $8: 1$ & $63840^{\mathrm{a}}$ & $21500^{\mathrm{a}}$ & $2.97^{\mathrm{a}}$ \\
\hline \multicolumn{6}{|c|}{ Chestnut tannin } \\
\hline Penicillium citrinum & $5.72 \pm 0.29^{b}$ & $35.15 \pm 0.57^{\mathrm{a}}$ & $0.024^{\mathrm{a}}$ & $0.09^{\mathrm{b}}$ & $0.28^{\mathrm{ab}}$ \\
\hline Penicillium aethiopicum & $5.45 \pm 0.10^{\mathrm{b}}$ & $35.51 \pm 0.23^{\mathrm{a}}$ & $0.023^{\mathrm{b}}$ & $0.13^{\mathrm{a}}$ & $0.25^{\mathrm{b}}$ \\
\hline Aspergillus chevalieri & $6.69 \pm 0.01^{\mathrm{a}}$ & $36.28 \pm 0.51^{\mathrm{a}}$ & $0.017^{\mathrm{c}}$ & $0.14^{\mathrm{a}}$ & $0.35^{\mathrm{a}}$ \\
\hline Aspergillus oryzae & $7.14 \pm 0.19^{a}$ & $30.77 \pm 0.47^{b}$ & $0.015^{\mathrm{d}}$ & $0.12^{\mathrm{ab}}$ & $0.43^{\mathrm{a}}$ \\
\hline \multirow{2}{*}{ Medium* } & $\begin{array}{c}\text { Total phenols } \\
(\%)\end{array}$ & $\mathrm{C} / \mathrm{N}$ ratio & $\begin{array}{c}\mathrm{COD} \\
\left(\mathrm{mgO} 2 \cdot \mathrm{L}^{-1}\right)^{\mathrm{B}}\end{array}$ & $\begin{array}{c}\text { BOD } \\
\left(\mathrm{mgO}^{2} \cdot \mathrm{L}^{-1}\right)^{\mathrm{B}}\end{array}$ & $\mathrm{COD} / \mathrm{BOD}^{\mathrm{B}}$ \\
\hline & $73 \pm 0.6^{\mathrm{a}}$ & $6: 1$ & $36480^{\mathrm{b}}$ & $13250^{\mathrm{b}}$ & $2.76^{\mathrm{b}}$ \\
\hline
\end{tabular}

* Total phenols, total carbon and nitrogen, COD and BOD: determined at the beginning of cultivation.

$\mu_{\max }$ is the maximum specific growth rate; $\mathrm{P}_{\mathrm{Xmax}}$ is the maximum biomass productivity; $\mathrm{Y}_{\mathrm{x} / \mathrm{s}}$ is the biomass yield on substrate.

Different superscript letters in the same column indicate a statistically significant difference $(p<0.05)$.

${ }^{\mathrm{A}}$ Standard deviation less than $10^{-4} ;{ }^{\mathrm{B}}$ Standard deviation less than $10^{-2}$. 
ratio ranged from $8: 1$ to $6: 1$ for acacia and chestnut tannin, respectively. For lipid production, it would be necessary to optimize the culture medium in order to increase the $\mathrm{C} / \mathrm{N}$ ratio of the medium. Lipid accumulation per liter of culture is usually optimal at molar C:N ratios exceeding 50 and near 100 (Ageitos et al., 2011). For instance, when optimum nutritional conditions for lipid production were studied for microbial lipid production by fungi, $\mathrm{C} / \mathrm{N}=31: 1$ and $\mathrm{C} /$ $\mathrm{N}=52: 1$ were found to be optimum, reaching $12.75 \%$ and $21.71 \%$ lipids for Penicillium citrinum and Aspergillus niger respectively (El-haj et al., 2015).

\section{Biodegradation potential of acacia and chestnut tannin}

The total phenols of tannins (Table 1) show that chestnut tannin presents a higher phenols content (73\%) when compared to acacia tannin (68\%), which corroborates the higher consumption of acacia tannin in cultivations. Mohanty and Jena (2017) reported that with the increase in the initial phenol concentration, a decrease in the percentage of phenol degradation was observed in cultures of Pseudomonas sp. NBM11. The presence of vegetable tannin in the effluent cause pollution problems that are usually toxic and xenobiotic. The residual amount of phenolic compounds is one of the major criteria of biodegradability. It has been found that the decomposition of phenolic compounds may significantly improve the biodegradability of preozonized phenolic compounds (Kanagaraj and Mandal, 2012). Aspergillus species have demonstrated efficiency in the degradation of phenolic compounds and has been used in the treatment of wastewater. Fungi of this genus use aromatic compounds through the production of catabolic enzymes (Rodrigues et al., 2007). It may be due to this efficiency that in the chestnut cultivations, where there was a higher content of total phenols, fungi of the genus Aspergillus and Penicillium had similar performance.

Vegetable tannins are usually regarded as biodegradable chemicals because they are natural products. Nevertheless, biodegradation behaviors of vegetable tannin extracts might vary greatly with their sources, molecular structures and molecular weights. A common property of tannins is that they can be employed as carbon and energy sources by many microorganisms (Shi and Di, 2000). Some microorganisms resistant to tannins have developed mechanisms and pathways for tannin degradation. Earlier reports suggest that Aspergillus niger and Penicillium ssp are capable of growing in tannic acid as sole carbon source (Silva et al., 2010). It was verified (Table 1) that all fungi assimilated acacia and chestnut tannin as a carbon source. The range of tannin consumption varied from $94.85 \%$ for Penicillium citrinum cultivated in acacia tannin to $30.77 \%$ for Aspergillus oryzae cultivated in chestnut tannin. These species have been reported as microbial sources of tannase. Filamentous fungi of the Aspergillus genus have been widely used for tannase production because it can occur in the absence of tannic acid. Phenolic compounds such as gallic acid, pyrogallol, methyl gallate, and tannic acid induces tannase synthesis. For instance, gallic acid such as tannic acid, has been reported as an inducer of tannase synthesis under submerged fermentation (Aguilar et al., 2007).

A particular property of vegetable tanning extracts is their hygroscopicity, miscible with water to form polydisperse solutions, partly of a colloidal type (Cassano et al., 2003). They are usually extensively used in processes of tanning and retanning so as to ensure full penetration of tannins and complete reaction between tannins and hides. Consequently, a part of tannins and of most non-tannins will inevitably remain in solution, which will lead to high loads of total solids and chemical oxygen demand (COD) in wastewater (Arana et al., 2001). During the tannage, tannins react with the hide fraction faster than non-tannin compounds. However, at the end of the process the concentration of tannin components is still significant. So the discharge of the bath represents an economical and environmental damage due to low biodegradability of tannins (Cassano et al., 2003). Compared with the aromatic syntans, aldehydic tanning agents and acrylic tanning agents, vegetable tannins are much easier to be biodegraded by tannery-activated sludge as reported by $\mathrm{He}$ et al. (2008). Meanwhile, hydrolysable tannin extracts exhibit better biodegradability than condensed tannin extracts. In this study, higher consumption of condensed tannin (acacia) was observed in relation to the hydrolysable tannin (chestnut) for all evaluated fungi. These results contradict the literature, which states that the condensed tannins are more resistant to degradation than hydrolysable tannins. Condensed tannins are not hydrolysed by classical tannases, with initial degradation steps carried out by monoor-di-oxygenases (Contreras- Dominguez et al., 2006). However, further studies are needed to further characterize the degradation of condensed tannin.

Earlier reports show that a concentration of tannins higher than $0.2 \mathrm{~g} / \mathrm{L}$ in wastewater strongly inhibits microbial activity, while $2 \mathrm{~g} / \mathrm{L}$ of tannins will completely inhibit it (Kalyanaraman et al., 2015). Besides that, the organic load removal is more sensitive to condensed tannin concentrations than to hydrolysable tannins (Dhayalan et al., 2007). According to Agustini et al. (2017), vegetable tannin in leather shavings showed an inhibitory effect for anaerobic biodegradation, where much of the residue underwent hydrolysis, but only a small part was mineralized to methane, resulting in an increase of organic matter. 
It is possible to estimate the biodegradability of an effluent and its environmental impact on a hydrous body. Traditionally, the concentration of organic matter in wastewater is measured by total organic carbon (TOC), dissolved organic carbon (DOC), biochemical oxygen demand (BOD), and chemical oxygen demand (COD) (Yang et al., 2014). The COD/ BOD ratio expresses a lot about what kind of oxidation will be effective in the degradation of the organic load. If $\mathrm{COD} / \mathrm{BOD}<2.5$, the compound is easily biodegradable. If $5.0>\mathrm{COD} / \mathrm{BOD}>2.5$ this effluent will require care in choosing the biological process so that there is a desirable removal of the organic load (Braga et al., 2012). As can be seen in Table 1, the acacia tannin presented a slightly higher COD/BOD ratio than that presented by chestnut tannin, 2.97 and 2.76 , respectively. With values greater than 2.5 for the $\mathrm{COD} / \mathrm{BOD}$ ratio, both are considered more difficult to be biodegraded.

Traditionally, the concentration of organic matter in wastewater is measured by total organic carbon (TOC), dissolved organic carbon (DOC), biochemical oxygen demand (BOD), and chemical oxygen demand (COD) (Yang et al., 2014).

The characterization of tannin extracts by FTIR has been published by several authors with the main aim of characterizing the extracts of different plants (Falcão and Araujo, 2013; Tondi and Petutschnigg, 2015; Grasel et al., 2016). In this context, FTIR was employed to evaluate the biodegradation of vegetable tannin by filamentous fungi (Figure 2). Phenols are organic compounds characterized by a hydroxyl groups bonded directly to an aromatic ring (benzene ring) (Blainski et al., 2013). Analysis of the spectra obtained shows peaks at 3000 to $3500 \mathrm{~cm}^{-1}$ due to the sum of the $\mathrm{OH}$ stretching that is characteristic of polyphenolic extracts. In addition, it could correspond to O-H stretch of the organic acids formed during the cultivation (Grasel et al., 2016).

The region of the spectra between 950 and 600 $\mathrm{cm}^{-1}$ features aromatic torsions, but mainly $\mathrm{C}-\mathrm{H}$ bending out-of-plane (Tondi and Petutschnigg, 2015). The condensed tannins show a more structured profile with a more intense absorption in the region between 1116 to $1110 \mathrm{~cm}^{-1}$ (Figure 2A), while the hydrolysable tannins present a major absorption at around 1731$1704 \mathrm{~cm}^{-1}$ and 1325-1317 $\mathrm{cm}^{-1}$ (Figure 2B) (Falcão and Araújo, 2014; Ricci et al., 2015). The peak at $1609 \mathrm{~cm}^{-1}$ for chestnut and $1612 \mathrm{~cm}^{-1}$ for acacia tannin correspond to $\mathrm{C}=\mathrm{C}$ of aromatic rings (Falcão and Araújo, 2014). The disappearance or reduction of peaks in this region suggests the breakage of $\mathrm{C}=\mathrm{C}$ bonds indicating the biodegradation of the condensed tannin, being more pronounced in the cultivations of Penicillium citrinum and Penicillium aethiopicum. The FTIR spectrum of the cultivations in chestnut tannin showed no significant change in the positions
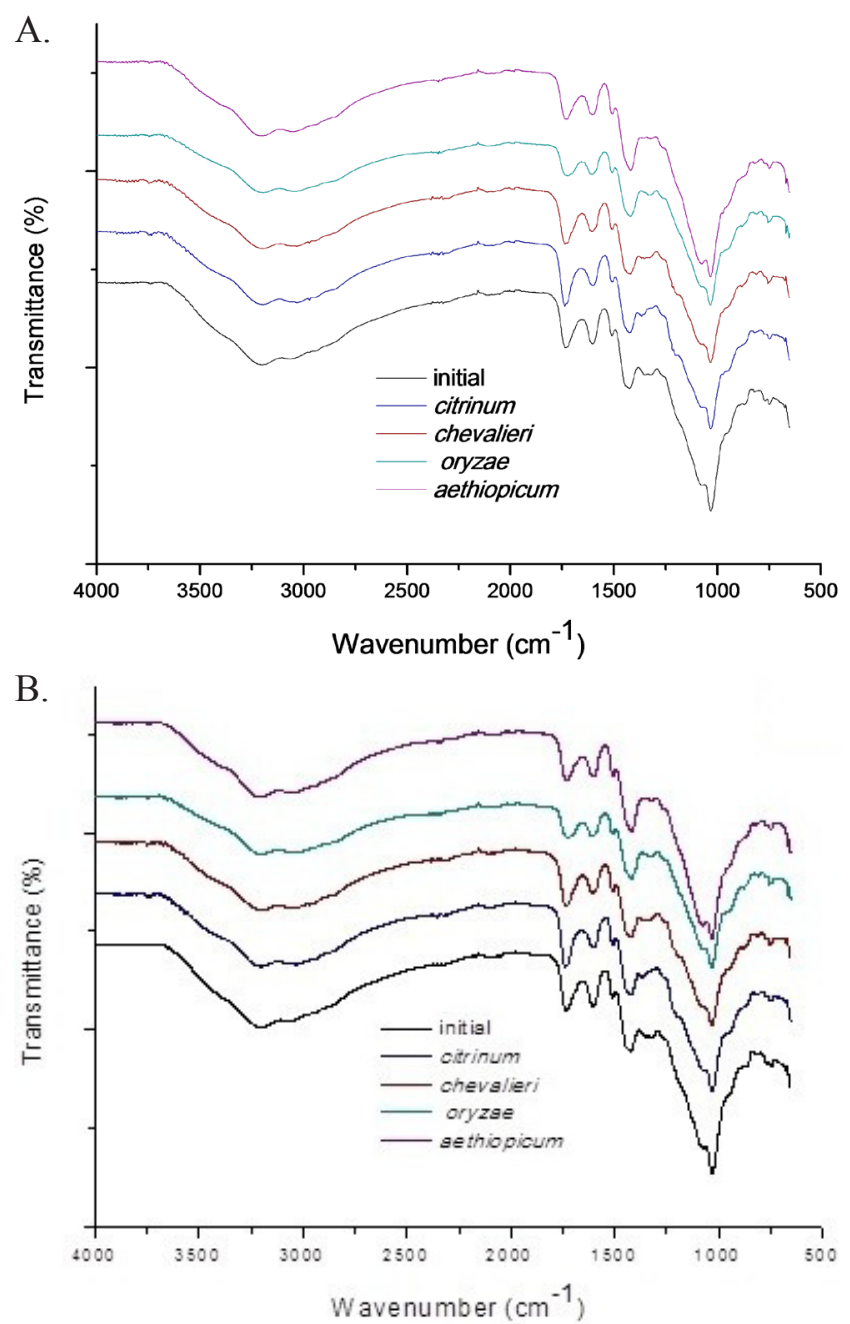

Figure 2. (A) FTIR spectrum of acacia and (B) FTIR spectrum of chestnut cultivation of Penicillium citrinum, Penicillium aethiopicum, Aspergillus chevalieri and Aspergillus oryzae.

or intensity of peaks (Figure 2B). This is probably due to the fact that there was low production of biomass and consumption of tannin in these cultivations.

Studies on enhancing the biodegradation of tannins by ozonation and Fenton's oxidation process (Kalyanaraman et al., 2015) have shown that the pre-ozonation improved the biodegradability and subsequent aerobic treatment carried out in batch aerobic reactors resulted in $\mathrm{BOD}_{5}$ and COD of 60 and $350 \mathrm{mg} / \mathrm{L}$ in the treated effluent. FT-IR results showed the presence of biodegradable organics like carboxylic acids, aldehydes and quinones in preozonated wastewater. Fenton pre-treatment resulted in a considerable increase in biodegradability with mineralization.

\section{CONCLUSIONS}

The present investigation was carried out in order to determine the potential of the fungi of the genera 
Penicillium and Aspergillus to biodegrade condensed and hydrolysable tannins. Penicillium citrinum and Penicillium aethiopicum were it to be more efficient, reaching $94.85 \%$ and $91.45 \%$ respectively for consumption of acacia tannin. In the chestnut cultivations the tannin consumption was low, not exceeding $36.28 \%$, there being no differences between the genera of the fungi. The acacia tannin presented a slightly higher COD/BOD ratio than that presented by chestnut tannin, 2.97 and 2.76 , respectively . On the other hand, chestnut tannin present a higher total phenols $(73 \%)$ compared to acacia $(68 \%)$. In this study, a higher consumption of condensed tannin (acacia) was observed in relation to the hydrolysable tannin (chestnut) for the evaluated fungi. The disappearance of peaks around $1600 \mathrm{~cm}^{-1}$ suggests the biodegradation of the condensed tannin by Penicillium citrinum and Penicillium aethiopicum. The expressive results obtained forom the consumption of acacia evidently suggest that the native isolates identified as Penicillium citrinum and Penicillium aethiopicum are efficient strains for the biodegradation of the tannin most used in tannery industry. Though some reports about tannin degradation by filamentous fungi are available, literature showing expressive consumption of a condensed tannin was not found. Therefore, the biodegradation of vegetable tannins by Penicillium citrinum and aethiopicum, Aspergillus chevalieri and oryzae may be a promising alternative.

\section{ACKNOWLEDGEMENTS}

The authors would like to thank Capes (Coordination for the Improvement of Higher Education Personnel - Edital 15/2014 - CAPES/EMBRAPA) for the scholarship.

\section{REFERENCES}

Adamczyk, B., Adamczyk, S., Smolander, A., Kitunen, V. Tannic acid and Norway spruce condensed tannins can precipitate various organic nitrogen compounds. Soil Biology and Biochemistry, 43, 628-637 (2011). https://doi.org/10.1016/j. soilbio.2010.11.034

Ageitos, J., Vallejo, J., Veiga-Crespo, P., Villa, T. Oily yeasts as oleaginous cell factories. Applied Microbiology and Biotechnology, 90, 1219 -1227 (2011). https://doi.org/10.1007/s00253-011-3200-z Aguilar, C.N., Rodríguez, R., Gutiérrez-Sánchez, G., Augur, C., Favela-Torres, E., Prado-Barragan, L.A., Ramírez-Coronel, A., Contreras-Esquivel, J.C. Microbial tannases: advances and perspectives. Applied Microbiology and Biotechnology, 76, 4752 (2007). https://doi.org/10.1007/s00253-007$1000-2$
Agustini, C.B., Spier, F., Costa, M., Gutterres, M. Biogas production for anaerobic co-digestion of tannery solid wastes under presence and absence of the tanning agent. Resources, Conservation \& Recycling, 130, 51-59 (2018). https://doi. org/10.1016/j.resconrec.2017.11.018

Anastasi, A., Parato, B., Spina, F., Tigini, V., Prigione, V., Varese, G.C. Decolourisation and detoxification in the fungal treatment of textile wastewaters from dyeing processes. New Biotechnology, 29, 38-45 (2011). https://doi.org/10.1016/j.nbt.2011.08.006

Araña, J., Tello Rendón, E., Doña Rodríguez, J.M., Herrera Melián, J.A., González Díaz, O., Pérez Peña, J. Highly concentrated phenolic wastewater treatment by the photo-Fenton reaction, mechanism study by FTIR-ATR. Chemosphere, 44, 1017-1023 (2001). https://doi.org/10.1016/S00456535(00)00359-3

Baccar, R., Blánquez, P., Bouzid, J., Feji, M., Attiya, H., Sarrà, M. Decolorization of a dye: From fungal screening to bioreactor application. Biochemical Engineering Journal, 56, 184-189 (2011). https:// doi.org/10.1016/j.bej.2011.06.006

Bhoite, R.N., Murthy, P.S. Biodegradation of coffee pulp tannin by Penicillium verrucosum for production of tannase, statistical optimization and its application. Food and Bioproducts Processing, 94, 727-735 (2015). https://doi.org/10.1016/j. fbp.2014.10.007

Blainski, A., Lopes, G., Mello, J. Application and analysis of the Folin Ciocalteu method for the determination of the total phenolic content from Limonium Brasiliense L. Molecules, 18, 6852-6864 (2013). https://doi.org/10.3390/ molecules 18066852

Braga, E.A.S., Aquino, M.D., Malveira, J.Q., Capelo-Neto, J., Alexandrino, C.D. Avaliação da biodegradabilidade das águas de lavagem provenientes da etapa de purificação do biodiesel produzido com óleo extraído das vísceras de tilápia. Revista de Gestão de Água da América Latina, 9, 35-45 (2012). https://doi.org/10.21168/rega.v9n2. p35-45

Cassano, A., Adzetb, J., Molinaric, R., Buonomennac, M.G., Roigb, J., Driolia, E. Membrane treatment by nanofiltration of exhausted vegetable tannin liquors from the leather industry. Water Research, 37, 2426-2434 (2003). https://doi.org/10.1016/ S0043-1354(03)00016-2

Chávez-González, M.L., Guyot, S., RodríguezHerrera, R., Prado-Barragán, A., Aguilar, C.N. Production profiles of phenolics from fungal tannic acidbiodegradation in submerged and solid-state fermentation. Process Biochemistry, 49, 541-546 (2014). https://doi.org/10.1016/j. procbio.2014.01.031 
Contreras-Dominguez, M., Guyot, S., Marnet, N., Le Petit, J., Perraud-Gaime, I., Roussos, S., Augur, C. Degradation of procyanidins by Aspergillus fumigatus: identification of a novel aromatic ring cleavage product. Biochimie, 88, 1899-1908 (2006). https://doi.org/10.1016/j.biochi.2006.07.011

Covington, A.D., Lampard, G.S. Studies on Semimetal Tanning. Journal of the American Leather Chemists Association, 99, 502-509 (2004).

Cruz-Hernández, M., Augur, C., Rodríguez, R., Contreras-Esquivel, J., Aguilar, C.N. Evaluation of culture conditions for tannase production by Aspergillus niger GH1. Food Technology and Biotechnology, 44, 41-544 (2006). https://doi. org/10.1515/znc-2005-11-1205

Cruz-Hernández, M., Contreras-Esquivel, J.C., Lara, F., Rodrigues, R., Aguilar, C.N. Isolation and evaluation of tannin-degrading fungal strains from the Mexican desert. Verlag der Zeitschrift für Naturforschung, 60, 844-848 (2005). https://doi. org/10.1515/znc-2005-11-1205

Eaton, A.D., Clesceri, L.S., Rice, E.W., Greensberg, A.E., Franson, M.A. Standard Methods for the Examination of Water \& Wastewater. American Public Health Association (APHA), Washington (2005).

El-haj, M., Olama, Z., Holail, H. Single Cell Oil of Oleaginous Fungi from Lebanese Habitats as a Potential Feed Stock for Biodiesel. International Journal of Current Microbiology and Applied Sciences, 7, 11-34 (2015).

Falcão, L., Araújo, M.E.M. Application of ATR-FTIR spectroscopy to the analysis of tannins in historic leathers: the case study of the upholstery from the $19^{\text {th }}$ century Portuguese Royal Train. Vibrational Spectroscopy, 74, 98-103 (2014). https://doi. org/10.1016/j.vibspec.2014.08.001

Falcão, L., Araújo, M.E.M. Tannins characterization in historic leathers by complementary analytical techniques ATR-FTIR. UV Vis and chemical tests. Journal of Cultural Heritage, 14, 499-508 (2013). https://doi.org/10.1016/j.culher.2012.11.003

Fuck, W.F., Gutterres, M., Marcílio, N.R., Bordingnon, $\mathrm{S}$. The influence of chromium supplied by tanning and wet finishing processes on the formation of $\mathrm{Cr}(\mathrm{VI})$ in leather. Brazilian Journal of Chemistry Engineering, 28, 221-228 (2011). https://doi. org/10.1590/S0104-66322011000200006

Grasel, F.S., Ferrão, M.F. A rapid and non-invasive method for the classification of natural tannin extracts by near infrared spectroscopy and PLSDA. Analytical Methods, 8, 644-649 (2016). https://doi.org/10.1039/C5AY02526E

Grasel, F.S., Ferrão, M.F., Wolf, C.R. Development of methodology for identification the nature of the polyphenolic extracts by FTIR associated with multivariate analysis. Spectrochimica Acta Part A, 153, 94-101 (2016). https://doi.org/10.1016/j. saa.2015.08.020

Guanamani, A., Sekaran, G., Badu, M. Removal of tannin from cross-linked and open chain polymeric tannin substrates using heme peroxidases of Phanerochaete chrysosporium. Bioprocess and Biosystems Engineering, 24, 211-217 (2001). https://doi.org/10.1007/s004490100256

Haroun, M., Khirstova, P., Covington, T. Tannins characterization of some indigenous and exotic woody plant species and two agricultural crops in Sudan. Journal of Forest Products \& Industries, 6, 38-46 (2013).

He, Q., Yao, K., Sun, C., Shi, B. Biodegradability of tannin containing wastewater from leather industry. Biodegradation, 18, 465-472 (2007). https://doi. org/10.1007/s10532-006-9079-1

He, Q., Sun, D., Xin, L., Wei, L., Shi, B. Evaluation of environmental impact of typical leather chemicals. Part III: Biodegradability of vegetable tannin extracts under activated sludge. Journal Society of Leather Technologists and Chemists, 92, 103-106 (2008).

Kalyanaraman, C., Kameswari, K.S.B., Rao, J.R. Studies on enhancing the biodegradation of tannins by ozonation and Fenton's oxidation process. Journal of Industrial \& Engineering Chemistry, 25, 329-337 (2015). https://doi.org/10.1016/j. jiec.2014.11.012

Kanagaraj, J., Mandal, A.B. Combined biodegradation and ozonation for removal of tannins and dyes for the reduction of pollution loads. Environmental Science and Pollution Reserch, 19, 42-52 (2012). https://doi.org/10.1007/s11356-011-0534-0

Khanbabaee, K., van Ree, T. Tannins: classification and definition. Natural Product Report, 6, 641-649 (2001).

Khot, M., Kamat, S. Zinjarde, S., Pant, A., Chopade, B., Ravikumar, A. Single cell oil of oleaginous fungi from the tropical mangrove wetlands as a potential feedstock for biodiesel. Microbial Cell Factories, 11, 1-13 (2012). https://doi.org/10.1186/14752859-11-71

Kyriacou, A., Lasaridi, K.E., Kotsou, M., Balis, C., Pilidis, G. Combined bioremediation and advanced oxidation of green table olive processing watewater. Process Biochemistry, 40, 1404-1408 (2005). https://doi.org/10.1016/j.procbio.2004.06.001

Luke, A.K., Burton, S.G.A. A novel application for Neurospora crassa: progress from batch culture to a membrane bioreactor for the bioremediation of phenols. Enzyme and Microbial Technology, 29, 348-356 (2001). https://doi.org/10.1016/S01410229(01)00390-8 
Maier, M., Oelbermann, A., Renner, M., Weidner, E. Screening of European medicinal herbs on their tannin content - New potential tanning agents for the leather industry. Industrial Crops and Products, 99, 19-26 (2017). https://doi.org/10.1016/j. indcrop.2017.01.033

Mohanty, S.S., Jena, H.M. Biodegradation of phenol by free and immobilized cells of a novel Pseudomonas sp. NBM11. Brazilian Journal of Chemical Engineering, 34, 75-84 (2017). https:// doi.org/10.1590/0104-6632.20170341s20150388

Muniraj, I.K., Xiao, L., Huc, Z., Zhan, X., Shi, J. Microbial lipid production from potato processing wastewater using oleaginous filamentous fungi Aspergillus oryzae. Water Research, 47, 3477-3483 (2013). https://doi.org/10.1016/j. watres.2013.03.046

Ortiz-Monsalve, S., Dornelles, J., Poll, E., RamirezCastrillón, M., Valente, P., Gutterres, M. Biodecolourisation and biodegradation of leather dyes by a native isolate of Trametes villosa. Process Safety and Environmental Protection, 109, 437-451 (2017). https://doi.org/10.1016/j.psep.2017.04.028

Pillai, P., Archana, G. A novel process for biodegradation and effective utilization of chrome shavings, a solid waste generated in tanneries, using chromium resistant Bacillus subtilis P13. Process Biochemistry, 47, 2116-2122 (2012). https://doi. org/10.1016/j.procbio.2012.07.030

Plavan, V., Valeika, V., Kovtunenko, O., Sirvaityte, J. THPS Pretreatment Before Tanning (Chrome or Nonchrome). Journal of the Society of Leather Technologists and Chemists, 93, 186-192 (2009).

Ricci, A., Olejar, K.J., Parpinello, G.P., Kilmartin, P.A., Versari, A. Application of fourier transform infrared (FTIR) spectroscopy in the characterization of tannins. Applied Spectroscopy Reviews, 50, 407442 (2015). https://doi.org/10.1080/05704928.201 4.1000461

Rodrigues, K.A., Sampaio, G.M.M., Zaiat, M., Santaella, S.T. Influência da glicose sobre o consumo de fenol por Aspergillus niger $400 \mathrm{em}$ reatores em batelada. Engenharia. Sanitária e Ambiental, 12, 222-228 (2007). https://doi.org/10.1590/S141341522007000200013

Saravanabhavan, S., Fathima, N.N., Rao, J.R., Nair, B.U. Combination of white minerals with natural tannins chrome free tannage for garment leathers. Jornal of the Society of Leather Technologists and Chemists, 91, 154-158 (2007).
Sartori, C.J., Castro, A.H.F., Mori, F.A. Teores de Fenóis Totais e Taninos nas Cascas de Angicovermelho (Anadenanthera peregrina). Floresta e Ambiente, 3, 394-400 (2014). https://doi. org/10.1590/2179-8087.061113

Shi, B., Di, Y. Vegetable polyphenol. Science Press, Beijing (2000).

Silva, I.S., Menezes, C.R., Franciscon, E., Santos, E.C., Durrant, L.R. Degradation of Lignosulfonic and Tannic Acids by Ligninolytic Soil Fungi Cultivated under Icroaerobic Conditions. Brazilian Archives of Biology and Technology, 53, 693699 (2010). https://doi.org/10.1590/S151689132010000300026

Song, Z., Burns, R.G. Depolymerisation and biodegradation of a synthetic tanning agent by activated sludges, the bacteria Arthrobacter globiformis and Comamonas testosteroni, and the fungus Cunninghamella polymorpha. Biodegradation, 16, 305-318 (2005). https://doi. org/10.1007/s10532-004-1723-Z

Sundar, V.J., Muralidharan, C. Salinity free high tannin fixation vegetable tanning: Commercial success through new approach. Journal of Cleaner Production, 142, 2556-2561 (2017). https://doi. org/10.1016/j.jclepro.2016.11.021

Teng, B., Jian, X., Gao, Y., Chen, W. Comparison of polyflavonoids in bayberry tanning effluent and commercial bayberry tannin: prerequisite information for vegetable tanning effluent recycling. Journal of Cleaner Production, 112, 972- 979 (2016). https://doi.org/10.1016/j. jclepro.2015.09.005

Tondi, G., Petutschnigg, A. Middle infrared (ATR FTMIR) characterization of industrial tannin extracts. Industrial Crops and Products, 65, 422-428 (2015). https://doi.org/10.1016/j.indcrop.2014.11.005

Valera, L.S., Jorge, J.A., Guimarães, L.H.S. Characterization of a multi-tolerant tannin acyl hydrolase II from Aspergillus carbonarius produced under solid-state fermentation. Electronic Journal of Biotechnology, 18, 464-470 (2015). https://doi. org/10.1016/j.ejbt.2015.09.008

Yang, L., Shin, H., Hur, J. Estimating the Concentration and Biodegradability of Organic Matter in 22 Wastewater Treatment Plants Using Fluorescence Excitation Emission Matrices and Parallel Factor Analysis. Sensors, 14, 1771-1786 (2014). https:// doi.org/10.3390/s140101771 
